\title{
Community Perceptions of New Residents in Penghu County, Taiwan
}

\author{
Shih-Mei Taia, Ya-Wen Oub, Shun-Da Jhao ${ }^{c}$
}

\begin{abstract}
In order to get close to and support the "new residents" of Penghu County, Taiwan (known as female foreign spouses, who are from mainland China and Southeast Asia), this study was conducted to set up a new service framework in the local community by the Penghu County Service Center for new residents. This study was implemented between May and July of 2011 to understand the local community perception of new residents living in five rural areas, and one city of Penghu, and to understand the community perceptions of these new residents. This includes: the new residents' feelings about the community, the new residents' feelings about interaction with the locals, multicultural acceptance of the community, and the new residents' feelings about participation in local activities. According to the parameters of this research, quantitative research methodology was adopted. After questionnaire studies and data analysis, the key findings are thus: New residents living areas have significant impact on the community perceptions of them, especially in two areas: the new resident's feeling relating to the community environment and their perception of interaction with the locals.
\end{abstract}

\section{Keywords}

Foreign spouse, community perception, immigrant, social work

In recent years, the Taiwanese government has clearly felt the increasing population of "new residents"1 (here referring to female foreign spouses, who are from mainland China and South East Asia). According to statistics from the Taiwan National Immigration Agency, the population of female foreign spouses was 432,000 in 2010 and increases by around 10,000 each year. Since 2002, Taiwan has introduced the Foreign and Mainland China Spouse Care Plan to provide better care and support for the new resident. The Foreign Spouse Caring Fund was created with the help of combining government resources with non-profit organizations. Penghu County (the only island county of Taiwan) also implemented a new resident care in 2003. Then Penghu County Service Center for New Residents was set up for case management and resources collaboration in 2007.
The Penghu County Service Center for New Residents has now been established for over eight years. In the first two years, it established the foundation of the service. The service was run under a structural organization model. In the third to seventh year, the operation was turned into case work for new cases, the goal being to stabilize individual case management. In the third year, the service began experimenting with external services to expand the

\footnotetext{
aMing Chuan University, Taiwan

bPenghu County Government, Taiwan

cTaiwanese Association of Social Work Supervisors (TW Supervisors), Taiwan

\section{Correspondent Author:}

Shih-Mei Tai, Department of Security Management and Community Affairs, 5 De Ming Rd., Gui Shan District, Taoyuan City 333, Taiwan
} 
services that the center could offer. Now, moving into the eighth year, the center is aiming to expand into local communities to create a service for the new resident, so that it can discover what these new residents need, and understand the current usage status of resources. The next step was to fully implement Penghu County's localized community services, which included plans to form more new resident service stops in the five townships and one city of Penghu so that it can get closer to understanding a new resident's living needs.

Technologies have had in the United States. Before illustrating this point in this comparative analysis, this paper provides a brief overview of the role of mass media in the US presidency prior to 1960.

Practical experience has found that female new residents are scattered throughout Penghu County (including five townships and one city). They are usually forced into the new environment and struggle to fit into the community because of the language barrier and culture difference. In Taiwan, these factors have caused several discourses and researches. However, many researches have focused on: (1) adaptation processes, as discussed by $\mathrm{Wu}$ (2004), Yang (2009), and $\mathrm{Wu}$ (2009); (2) multicultural differences, like Zhu (2002), Jiang, Chen, and Huang (2004), and $\mathrm{Zhu}$ and $\mathrm{Yu}$ (2005); and (3) some articles (Hsia 2000; Ye 2004; Wang 2007) talked about the connection between foreign spouse and the concept of "social capital", which is adopted from Narayan (1997), Tsai and Ghoshal (1998), Lin (1999), Winter (2000), Schuller (2000), and Schuller (2007).

A new resident in Taiwan not only has to cope with the husband's family life style and play the role of a caring mother, but also needs to live up to the expectations of her husband, her husband's family, her neighbors, even to the community's stereotype of a "foreign spouse". Owing to this, new residents experience both good and bad feelings from their local communities on a daily basis:
One foreign spouse said:

I used to love shopping at a grocery store near my house, but one day when I go shopping, I saw her watching "Do Not Call Me Foreign Spouse", a TV program, "all you foreign spouses were bought" she said, and in despise she doesn't even care that I'm standing right next to her. It made me so angry! (Bai 2011)

A Vietnam spouse said that her neighbors would look at her with curiosity. But once she sorted out her feelings, she treats her family with love, and is obedient to her husband's parents. After a while, people just get used to it. Now everyone calls her a good wife (Chen 2009).

Many years ago, an Indonesia spouse, who loved Lugu tea, joined "new resident tea art class", said that tea party can bring close people's feelings, no matter if they are families or friends. Through the smell of the tea, it can bring feelings closer (Lin 2010).

As soon as a new female resident steps out of her house and into the community, it is the community that becomes crucial as to whether or not these new residents are accepted. Therefore, in order for new residents to have a positive integration into the new community, it is most important to understand their true feelings about the community and the community perceptions towards them. As the researchers found in many research papers, most of them focused on how the locals feel towards new residents, yet none focused on how the new residents feel towards the community; how they feel about the new environment, how they feel about the interaction with the local, and how they feel about the community accepting multiculturalism, and these are the focuses of this research.

\section{PURPOSES}

This study hopes to understand new resident's opinion towards their community as well as better understand the perception of new residents in the community. 
This research can then act as a resource for new residents who come to Taiwan for the first time. It also gives the government and new resident service centers a better community overview when making expeditions out to the different townships. This research paper's primary goal is to focus on new residents (female foreign spouses people immigrating into Taiwan because of marriage).

The researchers' research focus is on "community perceptions" which include: community environment, interaction with locals, multicultural acceptance in the community, and participation in local activities. The objectives of this investigation are as follows:

(1) To understand the new residents' feelings towards the community environment;

(2) To understand the new residents' feelings regarding interacting with the locals;

(3) To understand the new residents' feelings on multicultural acceptance in the community;

(4) To understand the new residents' feelings about participating in local activities;

(5) To find out which background information (age, education, etc.) would affect the new residents' community perception.

\section{METHOD}

This study's primary target was to focus on the new residents as the researchers' research subjects. Based on the Penghu County Government Civil Administrations' Foreign and Mainland China Spouses Population Statistical Report, as of May 10, 2011, there were 1,035 foreign spouses, and 630 mainland China spouses, which totals 1,665 people. This will serve as the researchers' sample population.

\section{Study Variables and Study Design}

In this study, variables include:

Variables of the new residents' background information (individual factors) include: age, original nationality, years of living in Taiwan, years of living in the community, current location, and original education level.

The new residents' community perceptions are dependent variables, which include: (1) feelings towards the environment; (2) feelings towards the interaction with the locals; (3) multicultural acceptance in the community; and (4) opinions in regards to participating in local activities.

Then, the study framework is shown as the below Figure 1.

\section{Study Assumptions}

The assumptions are based on the research background and motivation, the reference discussion, research purpose, and the research structure for statistical usage and testing.

The list is as follows:

(1) New resident's community perception will be different due to age, original nationality, years living in Taiwan, time living in the community, current location, and original education level;

(2) New resident's feeling towards the environment will be different due to age, original nationality, years living in Taiwan, time spent living in the community, current locations, and original education level;

(3) New resident's feeling towards interaction with locals will be different due to age, original nationality, years living in Taiwan, time spent living in the community, current locations, and original education level;

(4) New resident's acceptance of multicultural will be different due to age, original nationality, years living in Taiwan, time spent living in the community, current locations, and original education level;

(5) New resident's participation in the local activities will be different due to age, original nationality, years living in Taiwan, time spent living in the community, current locations, and original education level. 


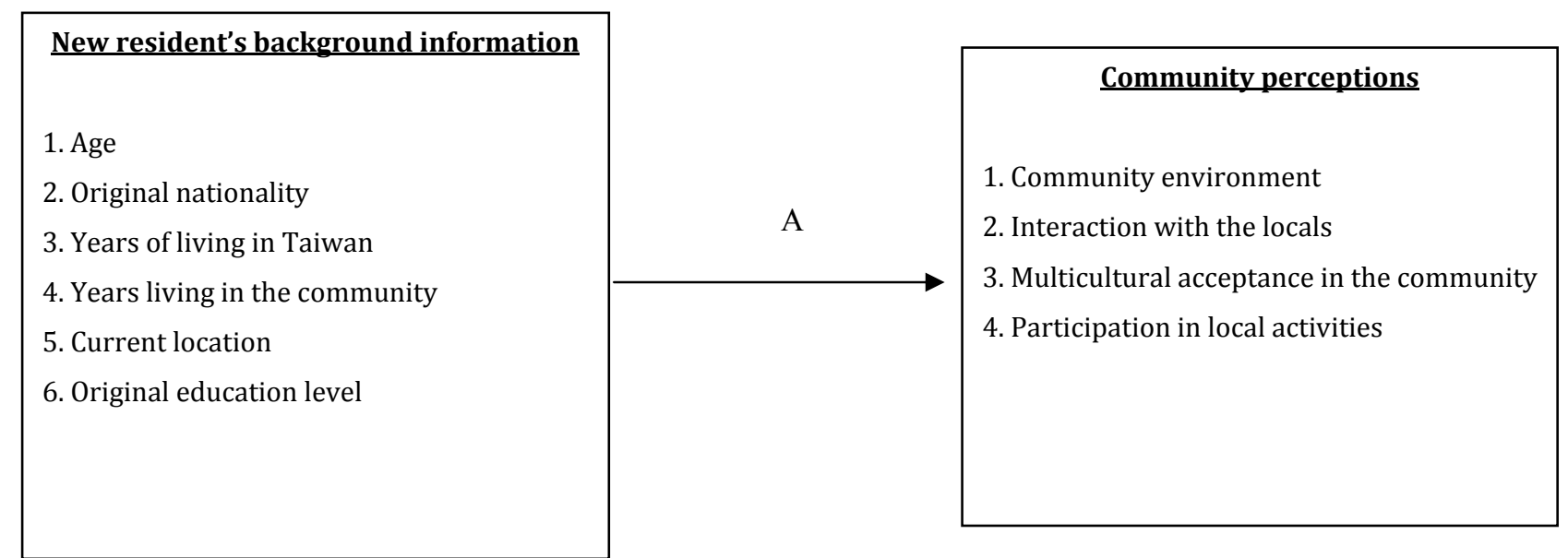

Figure 1. Research Structure Diagram.

Note: "A" represents the difference in how new resident's personal background could have an effect on community perceptions.

\section{Data Collection and Analysis}

Based on the Penghu County Government Civil Administrations' Foreign and Mainland China Spouses Population Statistical Report (May 10, 2011), there are 1,665 people in the sample population.

Due to Penghu County being an island chain, with large gaps in developed areas, this research was amended to make it more practical. The researchers did sampling based on the population of each area. Six point six six percent of each area of the new residents was selected to be included in this study. The actual samples for each area are shown in Table 1.

After data collection, the research study was returned with 250 valid surveys, out of a total 250 , with a return rate of $100 \%$. The content of this study was based on references on related subjects. The survey was then completed based on one-to-one interviews. The study participants were given directions on how to fill out the survey, and each was told that the study would be recorded anonymously.

Once the survey data have been sorted and recorded, it was processed using statistical software called SPSS (Statistic Package for Social Science) for Windows. Below is a list of the methods used in this research:

(1) New resident's background information used count distribution tables and percentage counts to calculate related statistical needs;

(2) One-Way ANOVA was used to understand the difference in community perceptions by age, original nationality, time living in Taiwan, time living in the community, current location, and original education level;

(3) One-Way ANOVA was used to understand the difference in feeling towards the community environment, the feeling towards interacting with the locals, the acceptance of multiculturalism by the locals, and the opinion of new resident participating in local activities by age, original nationality, time spent living in Taiwan, time living in community, current location, and original education level.

Most agree to follow the regulations when it comes to educational research (Fraenkel and Wallen 1996; Rudestam and Newton 1992; Tuckman 1994). It primarily includes respecting individual's will, securing personal privacy, to prevent physical or mental abuse, and to follow the code of trust and analyze and report without bias. 
Table 1. New Resident Population Sample Data

\begin{tabular}{llll}
\hline Area & New resident population & Sample size by location & Percentage (\%) \\
\hline Magong City & 779 & 117 & 46.8 \\
Huxi Township & 270 & 40 & 16.0 \\
Baisha Township & 190 & 29 & 11.6 \\
Xiyu Township & 242 & 36 & 14.4 \\
Wangan Township & 112 & 17 & 6.8 \\
Qimei Township & 72 & 11 & 4.4 \\
Total & 1,665 & 250 & 100 \\
\hline
\end{tabular}

Step 1. Respecting individual's will. When it comes to research on people, it is important to respect and protect the basic human's rights of the subject, thus, any participants' choice must have the chance to refuse. In other words, researchers are not able to research on an individual if the individual refuses. A participant who initially agrees also has the chance to withdraw at any point. Under the rule of respecting individual's will, researchers should try to avoid collecting unnecessary opinions or personal data, avoid noting down every reaction, and if the individual is not willing to participate, they should not force or persuade them.

Step 2. Securing personal privacy. To protect subject's personal interest and privacy, when performing educational research, results must be totally anonymous and confidential. While conducting data analysis, codes should be used to replace each participant to conceal their identity. After finishing the project, researchers should incinerate and destroy all raw data. If it was used by the study, then the forms should be mailed back to the subject directly, and not delivered to others.

Step 3. Not to endanger subjects physically and/or mentally. Not to endanger the test subject is one of the most important moral regulations. Researchers are responsible and have the duty to make sure that every test subject is not mentally or physically hurt, including long-term fear, etc.
Meanwhile, when designing research, researcher needs to carefully think how to minimize risks that could temporal cause mental or physical effects.

Step 4. Following the code of trust. Researches should always be trustworthy and should never lie. Things such as hiding one's identity, the goal of the research, and the research procedures, are forbidden. Not only does it not fit with research morality, but it also goes against society's code of honor, and it could also have a negative impact on the test subjects. This study followed the three rules in the code of trust: Firstly, not to hide the procedures from the test subjects; secondly, only withhold information when there is no other option, providing there are good scientific or educational goals for doing so; finally, if information has to be concealed temporarily, then the researchers must explain the reasons for doing so to the test subject as soon as possible after the test, but being careful when explaining, so as not to make the subject feel like they have been "tricked".

Step 5. Analyzing and reporting unbiased results. In research analogy, researchers should objectively analyze the data based on the research design. One must not intentionally remove negative or unexpected research data, so that the reader can fully grasp the results of the research. When reporting results, researchers are responsible to explain flaws and limitation of the research design, so that the reader can fully understand the reliability of the research. 


\section{Tools and Testing}

The study questionnaires are split into two parts: The first was the new residents' basic information including: date of birth, age, original nationality, time spent living in Taiwan, time living in the community, current location, and original education level; the second part was a questionnaire of community perceptions, including feelings towards the community environment, feelings about the interactions with the locals, multicultural acceptance within the community, and the opinion of the new residents' participation in local activities. The research study contains a total of 36 questions.

Background information. The new resident female background study design was based on Chen (2010), Y.-P. Huang (2010), Lin (2007), and other background studies, and was altered based on the needs of this research, including date of birth, original nationality, time living in Taiwan, time living in the community, current location, and original education level.

Community perceptions. This was based on works done by Y.-C. Huang (2010), Cho and Chen (2009), and other studies. The community perceptions part was developed under the guidance of the researcher's superiors and follows related research methods. It also used five-point Likert scale.

This study was based on reference discussion, and once the study was developed, it underwent several modifications. Professionals then went over the study to make sure it was credible. The study's questions were modified or removed following the valuable suggestions made by the professionals. In June 2011, 14 new residents were invited to a test, and had them answer the study questions and provide suggestions for modification. The interviewers were the three employees of the Penghu County Service Center for the New Residents. Before deploying the study, the three examiners were given training, explaining the content of the study, discussing each question, as well as interviewing skill and techniques. This study went under internal credibility testing. After the test, vague questions or phrases hard to understand were corrected and discussed with the researchers.

\section{Testing Sample Basic Data Analysis}

Based on the following description of reliability and effectiveness, it is clear that this research can use the reliability and effectiveness test to determine if the measuring tool was suitable for the task, and it can also serve as the guiding tool for error checking.

In this research, the testing sample basic characters were distributed as Table 2. After the test results were complete (see Table 3), the new residents' community observation $\alpha$ value was .8934 , therefore, the data result turned out well.

The five-point Likert scale was used, and based on their community perceptions experienced, it was split into "Absolutely yes, Maybe yes, Maybe no, Definitely not, and Not applicable", and their corresponding score was " $4,3,2,1$, and 0 points". In Section 1, Question 6, and Section 3, Question 3, the questions are set as "Reverse Scoring Questions", and must be scored in reverse. Based on the score of the participants, the higher the score is, the better the community perceptions are; likewise, a lower score signals poor community perceptions.

Section 2 of the community perceptions used 30 questions, which total 120 possible points. Researchers defined the score ranges of $0 \sim 45$ points as poor community perceptions, $45 \sim 77$ points as normal, and $77 \sim 120$ points as better community perceptions. Meanwhile, community perceptions were composed of four concepts, and the corresponding scores are as follows:

(1) "Feelings towards the community environment" were based on a total score of 40 points. $0 \sim 13$ points equal a poor experience with feelings to the community, 13 26 points mean normal experiences, and 26 40 points mean good experiences with feelings towards the community; 
Table 2. Testing Sample Basic Data Analysis

\begin{tabular}{|c|c|c|c|c|}
\hline Item & & Times & $\%$ & Total \\
\hline \multirow{3}{*}{ Age } & $21-30$ & 4 & 28.6 & \multirow{3}{*}{14} \\
\hline & $31-40$ & 9 & 64.3 & \\
\hline & Over 61 & 1 & 7.1 & \\
\hline \multirow{6}{*}{ Original nationality } & Vietnam & 3 & 21.4 & \multirow{6}{*}{14} \\
\hline & Indonesia & 3 & 21.4 & \\
\hline & Philippines & 1 & 7.1 & \\
\hline & Cambodia & 3 & 21.4 & \\
\hline & China & 3 & 21.4 & \\
\hline & Others & 1 & 7.1 & \\
\hline \multirow{3}{*}{ Years of living in Taiwan } & $3-5$ years & 1 & 7.1 & \multirow{3}{*}{14} \\
\hline & $5-7$ years & 1 & 7.1 & \\
\hline & Over 7 years & 12 & 85.7 & \\
\hline \multirow{4}{*}{ Years of living in community } & Under 1 year & 1 & 7.1 & \multirow{4}{*}{14} \\
\hline & $3-5$ years & 2 & 14.3 & \\
\hline & 5-7 years & 1 & 7.1 & \\
\hline & Over 7 years & 10 & 71.4 & \\
\hline \multirow{3}{*}{ Currently living area } & Magong City & 12 & 85.7 & \multirow{3}{*}{14} \\
\hline & Huxi Township & 1 & 7.1 & \\
\hline & Baisha Township & 1 & 7.1 & \\
\hline \multirow{3}{*}{ Original education level } & Elementary & 3 & 21.4 & \multirow{3}{*}{14} \\
\hline & Junior high & 5 & 35.7 & \\
\hline & Senior high & 6 & 42.9 & \\
\hline
\end{tabular}

Table 3. Creditability Analysis Table

\begin{tabular}{lll}
\hline Item & Question & $\alpha$ value \\
\hline Background information & $1 \sim 6$ & .9424 \\
Community perceptions & & \\
Community environment & $7 \sim 16$ & .7737 \\
Interaction with the locals & $17 \sim 26$ & .9256 \\
Multicultural acceptance & $27 \sim 31$ & .8875 \\
Participation in local activities & $32 \sim 36$ & .8242 \\
Total & $1 \sim 46$ & .8934 \\
\hline
\end{tabular}

(2) "Feelings about interaction with the local's environment" were based on a total score of 40 points. $0 \sim 13$ points equate to a poor experience of interaction with the locals, 13 26 points mean normal experiences of interactions with the locals, and 26 40 points mean good experiences of interaction with the locals;

(3) "Multicultural acceptance of the community" was based on a total score of 20 points. $0 \sim 6$ points mean poor acceptance of multiculturalism within the community, 6 14 points mean normal acceptance of multiculturalism within the community, and 14 20 points mean good acceptance of multiculturalism within the community;

(4) "Opinion of participation in local activities within the community" was based on a total score of 20 points. $0 \sim 6$ points mean a poor opinion of new residents participating in local activities, $6 \sim 14$ points 
mean a normal opinion of new residents participating in local activities, 14 20 points mean a good opinion of new residents participating in local activities.

\section{RESULTS AND DATA ANALYSIS}

The researchers hope to understand the effect on community perceptions using new resident's background information. Using assumptions and statistical software to process and calculate ANOVA and other related statistical test analysis, the results are as follows: Section 1-new resident's background data analysis, Section 2-new resident's community perceptions analysis, and Section 3-new resident's background data and community perceptions relationship analysis.

\section{New Resident's Background Data Analysis}

Based on 250 valid questionnaires, this section will discuss the background data of the research sample, including age, original nationality, years of living in Taiwan, years of living in the community, current living area and original education level, and categorized as shown in Table 4. Most of them live in Taiwan $(66.0 \%)$ and have resided in their current communities $(65.2 \%)$ for over seven years, $48.8 \%$ of them are 31-40 years old women.

\section{Community Perceptions Analysis}

Based on the data in Table 5, it shows that the new residents' feeling towards community environment $(26.56>26)$, interaction with the locals $(27.26>26)$, and participation in local activities $(14.09>14)$ are good, the feeling about multicultural acceptance in the community is normal $(12.69<14)$, and the total score of 80.62 reaches the good level of community perceptions.

\section{Background and Community Perceptions Interrelationship Analysis}

After analyzing age, original nationality, years of living in Taiwan, years of living in the community, current living area, and original education against community perceptions (Table 6), the researchers find that the new residents' community perceptions are not different because of a different age, original nationality, years of living in Taiwan, years of living in community, and original education level. The only factor which has a significant influence on the new residents' community perceptions is current living area $(\mathrm{F}=7.704, P=.000<.001)$.

According to the findings in Table 6, the researchers went a step further to compare the six different city/townships of current living area.

In Table 7 (see below), new residents' community perceptions will be different because of where they currently live and have a significant difference $(\mathrm{F}=$ 7.704, $P=.000<.001)$. This satisfies the research assumption: New residents' community perceptions will be different based on where they currently live. If we compared the means, we realized that Qimei Township's community perceptions (90.63) are higher than community perceptions of Xiyu Township (88.22), Huxi Township (84.77), Wangan Township (77.88), Magong City (77.78), and Baisha Township (74.65).

The new residents' feeling towards community environment will be different based on where they currently live and has a significant difference $(\mathrm{F}=$ 4.249, $P=.001<.01)$, this satisfies the research assumption that new residents' feeling towards the social environment will be different because of where they currently live. If we compared the means, we realized Qimei Township's feeling towards the social environment (28.54) is higher than feeling towards the social environment of Huxi Township (28.25), Xiyu Township (28.19), Magong City (26.09), Wangan Township (25.82), and Baisha Township (23.79).

After analyzing different locations where new residents live with feelings of locals interaction (Table 7), new resident's feelings on locals interaction are different based on where new residents live and have a 
Table 4. New Resident's Background Analysis

\begin{tabular}{|c|c|c|c|c|}
\hline Item & & Times & $\%$ & Total \\
\hline \multirow{5}{*}{ Age } & $21-30$ & 81 & 32.4 & \multirow{5}{*}{250} \\
\hline & $31-40$ & 122 & 48.8 & \\
\hline & $41-50$ & 35 & 14.0 & \\
\hline & $51-60$ & 7 & 2.8 & \\
\hline & Above 61 & 5 & 2.0 & \\
\hline \multirow{5}{*}{ Original nationality } & Vietnam & 110 & 44.0 & \multirow{5}{*}{250} \\
\hline & Indonesia & 48 & 19.2 & \\
\hline & Philippines & 2 & 0.8 & \\
\hline & Cambodia & 8 & 3.2 & \\
\hline & China & 82 & 32.8 & \\
\hline \multirow{5}{*}{ Years of living in Taiwan } & Under 1 year & 8 & 3.2 & \multirow{5}{*}{250} \\
\hline & $1-3$ years & 21 & 8.4 & \\
\hline & $3-5$ years & 21 & 8.4 & \\
\hline & $5-7$ years & 35 & 14.0 & \\
\hline & Over 7 years & 165 & 66.0 & \\
\hline \multirow{5}{*}{ Years of living in in community } & Under 1 year & 8 & 3.2 & \multirow{5}{*}{250} \\
\hline & $1-3$ years & 23 & 9.2 & \\
\hline & $3-5$ years & 20 & 8.0 & \\
\hline & 5-7 years & 36 & 14.4 & \\
\hline & Over 7 years & 163 & 65.2 & \\
\hline \multirow{6}{*}{ Currently living area } & Magong City & 117 & 46.8 & \multirow{6}{*}{250} \\
\hline & Huxi Township & 40 & 16.0 & \\
\hline & Baisha Township & 29 & 11.6 & \\
\hline & Xiyu Township & 36 & 14.4 & \\
\hline & Wangan Township & 17 & 6.8 & \\
\hline & Qimei Township & 11 & 4.4 & \\
\hline \multirow{6}{*}{ Original education level } & Uneducated & 7 & 2.8 & \multirow{6}{*}{250} \\
\hline & Elementary & 83 & 33.2 & \\
\hline & Junior high & 90 & 36.0 & \\
\hline & Senior high & 65 & 26.0 & \\
\hline & College & 3 & 1.2 & \\
\hline & Others & 2 & .8 & \\
\hline
\end{tabular}

Table 5. Community Perceptions Analysis Table

\begin{tabular}{lll}
\hline Item & Scores range & Average scores \\
\hline Community perceptions & $0-120$ & 80.62 (good) \\
Community environment & $0-40$ & 26.56 (good) \\
Interaction with the locals & $0-40$ & 27.26 (good) \\
Multicultural acceptance & $0-20$ & 12.69 (normal) \\
Participation in local activities & $0-20$ & 14.09 (good) \\
\hline
\end{tabular}


Table 6. Background Variables VS Community Perceptions ANOVA

\begin{tabular}{lll}
\hline \multirow{2}{*}{ Variables } & \multicolumn{2}{c}{ F test } \\
\cline { 2 - 3 } & $\mathrm{F}$ & Significant \\
\hline Age & .897 & .466 \\
Original nationality & .824 & .511 \\
Years of living in Taiwan & 1.328 & .260 \\
Years of living in community & 1.125 & .345 \\
Current living area & 7.704 & $.000^{* * *}$ \\
Original education level & 3.567 & .055 \\
& Mean =13.260 \\
$\mathrm{N}=250$ & Standarddeviation $=80.62$ & \\
\hline
\end{tabular}

Note: ${ }^{* * *} p<.001$.

Table 7. Current Living Area and Community Perceptions ANOVA

\begin{tabular}{|c|c|c|c|c|c|c|}
\hline \multirow[b]{2}{*}{ Current living area } & \multirow[b]{2}{*}{$\mathrm{N}$} & \multicolumn{5}{|c|}{ Mean scores } \\
\hline & & Total & $\begin{array}{l}\text { Community } \\
\text { environment }\end{array}$ & $\begin{array}{l}\text { Interaction with } \\
\text { locals }\end{array}$ & $\begin{array}{l}\text { Multi-cultural } \\
\text { acceptance }\end{array}$ & $\begin{array}{l}\text { Activities } \\
\text { participation }\end{array}$ \\
\hline (1) Magong City & 117 & 77.78 & 26.09 & 26.01 & 12.51 & 13.17 \\
\hline (2) Huxi Township & 40 & 84.77 & 28.25 & 28.30 & 13.17 & 15.05 \\
\hline (3) Baisha Township & 29 & 74.65 & 23.79 & 25.68 & 11.51 & 13.65 \\
\hline (4) Xiyu Township & 36 & 88.22 & 28.19 & 30.22 & 13.44 & 16.36 \\
\hline (5) Wangan Township & 17 & 77.88 & 25.82 & 26.52 & 12.94 & 12.58 \\
\hline (6) Qimei Township & 11 & 90.63 & 28.54 & 32.45 & 13.18 & 16.45 \\
\hline Total & 250 & 80.62 & 26.56 & 27.26 & 12.69 & 14.09 \\
\hline
\end{tabular}

significant difference $(\mathrm{F}=4.249, P=.001<.05)$, this satisfies the research assumption that "the new resident's feelings on interaction with the locals will be different due to current living area". If we compare the means, we find that Xiyu Township's (30.22) feelings on locals interaction are greater than feelings on locals interaction of Qimei Township (28.54), Huxi Township (28.30), Wangan Township (26.52), Magong City (26.01), and Baisha Township (25.68).

However, after analyzing different locations where new residents live with the community multicultural acceptance score, new residents' acceptance of multiculturalism will be different based on where they currently live, and is significantly different $(\mathrm{F}=2.203$, $P=.055>.05)$, this does not satisfy the research assumption that the new residents' acceptance of multiculturalism will be different due to where they currently live. After analyzing different locations where new residents live with new resident's opinion on participating in community activities as shown in Table 7, new residents' participation with social activities will be different based on where they currently live and has a significant difference $(\mathrm{F}=$ $2.203, P=.055>.05)$. This does not satisfy the research assumption that, "the new residents' participation with social activities will be different because of where they currently live".

To summarize, accepted assumptions of this study are as follows:

(1) New residents' community perceptions will be different based on where they currently live (Qimei Township > Xiyu Township $>$ Huxi Township $>$ Wangan Township $>$ Magong City $>$ Baisha Township);

(2) New residents' feeling towards community environment will be different based on where they 
currently live (Qimei Township > Huxi Township > Xiyu Township $>$ Magong City $>$ Wangan Township > Baisha Township);

(3) New residents and the interaction with the community locals will be different due to where they currently live (Xiyu Township > Qimei Township > Huxi Township > Wangan Township > Magong City > Baisha Township);

(4) New residents and the interaction with the community locals will be different based on the original education level (Elementary $>$ Junior High $>$ Senior High $>$ Uneducated $>$ College $>$ Others).

\section{CONCLUSIONS}

This study is practical research, primarily focused on finding the relationship between new resident's background information with social support and community perceptions. First, the researchers collected and studied any subject area based on social resources, community perceptions, and new resident's related theory, and used it as the foundation for this new research. Next, on finding support for this research, the researchers used Penghu's new residents as the sample pool, and randomly selected 250 people. In this section, the researchers will make conclusions based on each research result. This can then be used as a future reference for any new resident related service stop program framework.

Research has found that new residents' community perceptions will be different based on where they currently live, and from four community perceptions: feeling towards the social environment, with feelings on local's interaction, community acceptance of multiculturalism, and new resident's opinion on participating in local activities. The statistical analysis has all shown a significant difference. The researchers analyzed these factors and realized that Qimei Township, Xiyu Township, and Huxi Township are areas that scored higher in community perceptions, whereas Magong City,
Wangan Township, and Baisha Township fell under the normal range for community perception. The researchers defined new resident's acceptance for community perceptions into poor, normal, and better, and for each category, the corresponding scores of 0 45 points, 45 77 points, and 77 120 points. Qimei Township (90.63), Xiyu Township (88.22), and Huxi Township (84.77) all belong to the better category, whereas Wangan Township (77.88), Magong City (77.78), and Baisha Township (74.65) have scores closer to the normal category. Since the latter three have a significant difference in score with the first three, the researchers categorize the latter three as a normal class. Researchers believe that it is possible to focus on these areas to provide and develop related support plans and services to raise its community perceptions score.

Based on the current results and the conclusions drawn, this research suggests that the following suggestions can be used as a reference to those currently working under new resident related business.

\section{A Need to Pay Close Attention to New Resident's Living Needs, Instead of Their Living Condition and/or Rights, Prior to Coming to Taiwan}

Research shows that new residents with an age range of 31-60 years old require more social support. This means that this service group requires more attention than others. Most of the current services are more focused on pre-living requirements or identity rights as service goals. People believe that before new residents naturalized, they require short-term services; however, people are overlooking the real long-term need to be able to live in Taiwan, such as information about how to obtain citizen identification cards, and how to treat them as normal women under social benefit laws. It is suggested that there is a service set up for these elderly new residents for a spouse benefit service center, to train professionals and to make useful resources, so that there is a better service 
provision to these individuals. Things such as predictive and supportive service plans will hopefully raise new resident's social support ability to a level where they can stand on their own two feet.

\section{Expand Services to Areas That Are Far out of Reach}

As a whole, most of the service cases are focused in Magong City, meaning Magong has the most varied services. Because of this research, it is clear that Baisha Township requires more help in community perception. Also, owing to Baisha Township's geographic issues, the towns are not grouped easily, making the supply of resource less efficient than other townships. It is recommended that we develop more service expansion plans, for example, more new resident service locations, popularizing multiculturalism with locals, and to increase the interaction of the new residents with the locals.

\section{Set and Enforce Unofficial Support System Plans}

Overall, female new resident's social support has a direct effect on their community perception. It is hoped that using unofficial support systems will not only increase their relationships with others, but also allow exchange of experiences of how to cope with immigration, child development, cultural information, etc., so that the new residents have a way of relieving stress.

\section{Develop Community Gurus}

Currently, there is a new resident service support center in Penghu County; it is located inside Huxi Community Activity Center, Huxi Township, and provides new resident local support. It is recommended that government should expand new resident's service locations and the numbers of such service locations, to provide a location for new residents to meet, communicate, and develop unofficial support networks in order to acquire information and helpful resources. Hopefully, we can find new female residents who are willing to promote multicultural topics, and educate them as community gurus to help community locals to understand multiculturalism and respect. Also reinforcing the female new residents' independence and self-confidence, as well as assisting other female new residents to speak up, direct them to related new resident's departments, connect them with social benefit resources, and to increase new residents' community belonging and acknowledgement.

\section{APPENDIX: QUESTIONNAIRES' CODING BOOK}

\begin{tabular}{|c|c|c|}
\hline \multicolumn{3}{|l|}{ Background information } \\
\hline Age: & \multicolumn{2}{|l|}{ _years old } \\
\hline Original nationality: & \multicolumn{2}{|c|}{$\begin{array}{l}\text { 1. Vietnam; 2. Indonesia; 3. The Philippines; 4. Cambodia; 5. Mainland China; } 6 . \\
\text { Any other (specify): }\end{array}$} \\
\hline Years of living in Taiwan: & \multicolumn{2}{|c|}{ 1. Under a year; $2.1-3$ years; $3.3-5$ years; $4.5-7$ years; 5.7 years or more } \\
\hline Years of living in the community: & \multicolumn{2}{|l|}{ About_year(s) } \\
\hline Currently living in: & \multicolumn{2}{|c|}{$\begin{array}{l}\text { 1. Ma-gong City; 2. Hu-xi Township; 3. Bai-sha Township; 4. Xi-yu Township; } 5 . \\
\text { Wang-an Township; 6. Qi-mei Township }\end{array}$} \\
\hline Original education level: & \multicolumn{2}{|c|}{$\begin{array}{l}\text { 1. Uneducated; 2. Elementary school; 3. Junior-High school; 4. Senior-High school; } \\
\text { 5. College; 6. Master degree; 7. Any Other (specify):_ }\end{array}$} \\
\hline \multicolumn{3}{|l|}{ Perceptions of the community } \\
\hline \multicolumn{3}{|c|}{ I . Feelings towards your community environment } \\
\hline \multicolumn{2}{|c|}{ Most of the people are trust-worthy in the community that I live in. } & 0. Not applicable \\
\hline \multicolumn{2}{|c|}{ The community that I currently live in is safe. } & 1. Definitely not \\
\hline \multicolumn{2}{|l|}{ Walking in the streets at night is safe. } & 2. Maybe not \\
\hline
\end{tabular}




\begin{tabular}{|c|c|}
\hline I feel that the community which I lived in is very courteous. & \multirow{7}{*}{$\begin{array}{l}\text { 3. Maybe yes } \\
\text { 4. Absolutely yes }\end{array}$} \\
\hline I feel like this community can be a place for me to live in forever. & \\
\hline I feel lonely because I felt it was caused by different nationalities. & \\
\hline $\begin{array}{l}\text { I think there are people in the community, other than my family, who can assist me to understand } \\
\text { any needed information or regulation for being a new resident. }\end{array}$ & \\
\hline $\begin{array}{l}\text { I think there are people in the community, other than my family, who can assist me with any } \\
\text { needed language training or activities for being a new resident. }\end{array}$ & \\
\hline $\begin{array}{l}\text { I think there are people in the community, other than my family, who can assist me to know all of } \\
\text { Penghu's new resident service centers. }\end{array}$ & \\
\hline \multirow{2}{*}{\multicolumn{2}{|c|}{\begin{tabular}{|l|} 
I do not feel alienated or fear in the community that I am living in. \\
II. Feelings regarding interacting with the locals \\
\end{tabular}}} \\
\hline & \\
\hline There are known friends or neighbors in the community I am currently living in. & \multirow{10}{*}{$\begin{array}{l}\text { 0. Not applicable } \\
\text { 1. Definitely not } \\
\text { 2. Maybe not } \\
\text { 3. Maybe yes } \\
\text { 4. Absolutely yes }\end{array}$} \\
\hline I'd invite someone into the house if his/her car broke down in front of my house. & \\
\hline Neighbors would help when I needed help. & \\
\hline I could ask the neighbors to watch over my children if I were to head out. & \\
\hline Neighbors and I often visit each other's houses. & \\
\hline I am familiar with who lives around my house. & \\
\hline I will take initiative on making chances to know new neighbors. & \\
\hline I am willing to help my neighbors when they are sick or injured. & \\
\hline I usually meet friends or acquaintances while I do grocery shopping in the community. & \\
\hline I am satisfied with relationships with my neighbors within this year. & \\
\hline \multicolumn{2}{|l|}{ III. Multicultural acceptance in community } \\
\hline I feel the community has a bad impression with new residents from out of the country. & \multirow{5}{*}{$\begin{array}{l}\text { 0. Not applicable } \\
\text { 1. Definitely not } \\
\text { 2. Maybe not } \\
\text { 3. Maybe yes } \\
\text { 4. Absolutely yes }\end{array}$} \\
\hline A lot are willing to talk about each other lives in my community. & \\
\hline I feel I can show my country's culture and traditions without being limited. & \\
\hline $\begin{array}{l}\text { I feel if I were to participate with the celebrations, tradition activities, or local activities, I will not } \\
\text { be alienated or being treated differently. }\end{array}$ & \\
\hline \multirow{2}{*}{\multicolumn{2}{|c|}{\begin{tabular}{|l|} 
The locals are very respectful of my language and opinions. \\
IV. Opinions in regards to participating local activities as a new resident
\end{tabular}}} \\
\hline & \\
\hline $\begin{array}{l}\text { The community often hosts activities that I can participate with the locals (such as local activities, } \\
\text { new resident activities, or promotions). }\end{array}$ & \\
\hline $\begin{array}{l}\text { I believe there are activities that are suitable for me to participate (such as local activities, } \\
\text { promotions, or new resident activities). }\end{array}$ & $\begin{array}{l}\text { 1. Definitely not } \\
\text { 2. Maybe not }\end{array}$ \\
\hline $\begin{array}{l}\text { I believe the community activities (such as local activities, promotions, or new resident activities) } \\
\text { are temping for me to get participate in. }\end{array}$ & $\begin{array}{l}\text { 3. Maybe yes } \\
\text { 4. Absolutely yes }\end{array}$ \\
\hline \multirow[t]{2}{*}{ I am willing to join when the community activities require assistance. } & \\
\hline & \\
\hline
\end{tabular}

\section{Acknowledgements}

This field research cooperated with Penghu New Resident Center. The researchers would like to express gratitude to the participants of this research. The researchers also want to express their gratitude to Ms. Yu-Shan Huang who helps read and correct the draft of this paper.

\section{Note}

1. This term is used instead of foreign spouses so as to avoid prejudice and discrimination.

\section{References}

Bai, Y.-J. 2011. "Strive for Friendly Treatment, Woman Without Fear." Taiwan Legislature Newsletter. Retrieved May 16, 2011 (http://tw.news.yahoo.com/).

Bernosky de Flores, C. H. 2010. "A Conceptual Framework for the Study of Social Capital in New Destination Immigrant Communities." Journal of Transcultural Nursing 21:205-211.

Bourhis, R. Y., G. Barrette, S. El-Geledi, and R. Schmidt. 2009. "Acculturation Orientations and Social Relations Between Immigrant and Host Community Members in California." 
Journal of Cross-Cultural Psychology 40:443-467.

Chen, C.-F. 2009. Foreign Spouses Settle Hope Speed Into Taiwan Society. Retrieved October 25, 2009 (http://www. epochtimes.com/).

Chen, M.-Y. 2010. The Influence of the New Immigrants in Taiwan: Cultural Identity, Family Status and Social Support. Ilan: Fob Guan University.

Cho, C. and Y.-R. Chen. 2009. "Social Welfare Privatization in Practice and Reflections-A Case Study of Community Care Caring Presence to Implement." Presented at Civil Society and Human Rights Development Symposium, May 13, Department of Administration, National Tainan University, Tainan.

Dassopoulos, A. and S. M. Monnat. 2011. "Do Perceptions of Social Cohesion, Social Support, and Social Control Mediate the Effects of Local Community Participation on Neighborhood Satisfaction?" Environment and Behavior 43:546-565.

Fraenkel, J. R. and N. E. Wallen. 1996. How to Design and Evaluate Research in Education. NY: McGraw-Hill.

Hsia, H.-C. 2000. "Social Capital Under the International Marriage: 'Foreign Brides' Phenomenon in Taiwan.” Social Research Quarterly 39:45-92.

Huang, Y.-C. 2010. The Relationship Between Social Capital, Volunteering and Community Safety-A Case Study in Kinmen County Headquarters Before. Kaohsiung: University of Kaohsiung.

Huang, Y.-P. 2010. Cognition of Community Citizens and Students to Participate in Community Forestry, Attitudes, Satisfaction: A Case Study of Qu-xi Community. Chiayi: University of Chiayi.

Jiang, L.-A., Y.-Z. Chen, and Z.-C. Huang. 2004. "Foreign Spouse's Life Adaptation." Journal of Community Development 105:66-89.

Lin, H.-L. 2010. Integrate Into Taiwan Society New People to Share Experiences. Retrieved October 24, 2010 (http://www.epochtimes.com/).

Lin, N. 1999. "Building a Network Theory of Social Capital." Connections 22(1):28-51.

Lin, Y.-D. 2007. Community Residents' Participation of Economic and Social Activities in the Relationship With Social Capital: A Case of Su-auo White Rice Community. Taichung: Fang Chia University.

Montreuil, A. and R. Y. Bourhis. 2001. "Majority Acculturation Orientations Toward 'Valued' and 'Devalued' Immigrants." Journal of Cross-Cultural Psychology 32:698-717.

Narayan, D. 1997. Voices of the Poor: Poverty and Social Capital in Tanzania. Environmentally and Socially Sustainable Development Studies and Monographs Series 20. Washington, D.C.: The World Bank. Pp. 1-20.
Neufeld, A., M. J. Harrison, M. S. Stewart, K. D. Hughes, and D. Spitzer. 2002. "Immigrant Women: Making Connections to Community Resources for Support in Family Caregiving." Qualitative Health Research 12:751-768.

Regis, A. H. 1988. "Communication and the Sense of Community Among the Members of an Immigrant Group." Journal of Cross-Cultural Psychology 19:329-340.

Rose, G. 1995. Place and Identity. Pp. 87-132 in A Place in the World? Places, Cultures and Globalization, edited by D. Massey and P. Jess. UK: The Open University.

Rudestam, K. and R. R. Newton. 1992. Surviving Your Dissertation. Thousand Oaks, CA: Sage.

Sarason, I. G., H. M. Levine, R. B. Basham, and B. R. Sarason. 1983. "Assessing Social Support: The Social Support Questionnaire." Journal of Personality and Social Psychology 44(1):127-139.

Schuller, T. 2000. "Social and Human Capital: The Search for Appropriate Technomethodology." Policy Studies 21(1):1-13.

- 2007. "Reflections on the Use of Social Capital." Journal of Review of Social Economy 65(1):11-28.

Stone, W. and J. Hughes. 2000. "What Role for Social Capital in Family Policy-And How Does It Measure up?" Presented at the 7th Australian Institute of Family Studies Conference, July 24-26, 2000, Sydney.

Taiwan National Immigration Agency. 2010. Report on Foreign Spouse Population in Taiwan. Retrieved March 12, 2011 (http://www.immigration.gov.tw/).

Tsai, W. and S. Ghoshal. 1998. "Social Capital and Value Creation: The Role of Intra-firm Networks." The Academy of Management Journal 41(4):464-476.

Tuckman, B. W. 1994. Conducting Educational Research. 5th ed. TX: Harcourt Brace College Publishers.

Wang, S.-Y. 2007. "Accumulated Foreign Spouses' Social Capital by the Formation of Social Support Networks." Journal of Community Development 102(119):84.

Winter, I. 2000. "Social Capital and Public Policy in Context." In Social Capital and Public Policy in Australia, edited by I. Winter. Melbourne: Australian Institute of Family Studies.

$\mathrm{Wu}$, M.-J. 2009. "Community the Multicultural Social Inclusion Explore: A New Immigrant Women in Taiwan, for Example." Journal of Community Development 112(127):99.

Wu, S. 2004. Mainland Female Spouses Life Adaptation in Taiwan-Taipei County, for Example. Kaohsiung: National Sun Yat-Sen University.

Yang, X.-C. 2009. The New Immigrant Women Under Globalization: Foreign Spouses, Social Exclusion and Social Integration in Taiwan. Taipei: Soochow University.

Ye, S.-C. 2004. "Foreign Spouses, Including: Social Capital and Social Cohesion." Journal of Community Development 
105:133-150.

Zhu, Y.-L. 2002. Discussion on the Life Experiences of Foreign Brides of Penghu. Chiayi: National Chiayi University's Institute for Family Education.

Zhu, Z.-R. and D.-R. Yu. 2005. "Taiwanese Attitude to the Immigration Policy on Foreign Spouse." Journal of Taiwan Sociology 10:95-148.

\section{Bios}

Shih-Mei Tai, Ph.D., assistant professor, Department of
Security Management and Community Affairs, Ming Chuan University, Taiwan; research fields: violence against women, community work, social work practice.

Ya-Wen Ou, BSW, social work supervisor, Penghu New Resident and Family Service Center, Department of Social Affairs, Penghu County Government, Taiwan; research fields: foreign spouse case management, networking, female immigrant law and policy.

Shun-Da Jhao, BSW, secretary, Taiwanese Association of Social Work Supervisors (TW Supervisors), Taiwan; research fields: project management, non-profit organization, social work platform. 